\title{
TECHNOLOGY ACCEPTANCE OF FINANCIAL TECHNOLOGY (FINTECH) FOR PAYMENT SERVICES AMONG EMPLOYED FRESH GRADUATES
}

\author{
Shamsurin Ahmad ${ }^{1}$, Sharina Tajul Urus ${ }^{2 *}$ and \\ Sharifah Nazatul Faiza Syed Mustapha Nazri² \\ ${ }^{1}$ Faculty of Accountancy, \\ Universiti Teknologi MARA, Shah Alam, Malaysia \\ ${ }^{2}$ Faculty of Accountancy, \\ Universiti Teknologi MARA, Kampus Puncak Alam, Malaysia
}

\section{ABSTRACT}

The Fourth Industrial Revolution (IR 4.0), which is complementary to the technological revolution, has given birth to Financial Technology (Fintech). Numerous advantages are offered by Fintech, yet the adoption rate is still low. This is especially from the employed fresh graduates' perspectives that are regarded as the computer literate and IT savvy's group. This research aims to examine the factors that affect the technology acceptance of Fintech payment services. The research attempts to measure the relationships between performance expectancy, effort expectancy, social influence, facilitating condition and consumers' trust with the adoption of Fintech. Based upon the Unified Theory of Acceptance and Use of Technology (UTAUT), the quantitative method was employed via online survey of 179 respondents. The result showed that consumers' trust had the highest impact on the adoption of Fintech payment services, followed by performance expectancy and effort expectancy. In contrast, facilitating conditions and social influence showed an insignificant relationship with the adoption of Fintech payment services. This finding would enhance the awareness for people to become more open towards the acceptance of Fintech for their daily transactions. Fintech companies are expected to develop into more secure services and design better products in becoming a cashless society.

Keywords: UTAUT, consumers' trust, financial technology, Fintech, Fintech payment services adoption, employed fresh graduates

\section{ARTICLE INFO}

\section{Article History:}

Received: 18 May 2021

Accepted: 14 July 2021

Published: 31 August 2021

* Corresponding Author: Sharina Tajul Urus. E-mail: sharina675@uitm.edu.my 


\section{INTRODUCTION}

The Fourth Industrial Revolution (IR 4.0), which is complementary to the technological revolution, has given birth to Financial Technology (Fintech). Fintech is a phenomenon fueled by the World Wide Web and mobile Internet revolution. Fintech is used to describe new technology that seeks to improve and automate the delivery and use of financial services. PwC (2016) postulated that Fintech is a combination of financial and technological innovation, where technology is implemented into the products and services that financial institutions usually provide to consumers. It is a strategic approach to ensure that the financial institution can provide efficient and effective financial services. Meanwhile, Dorfleitner, Hornif, Schmitt, and Weber (2017) suggested four categories of Fintech which include asset management, financing, payments, and other types based on the distinctive business models. For instance, Fintech covers a broad range of services, including payments, cryptocurrency, peer-to-peer (P2P) lending, Insurtech, crowdfunding and others. Fintech payment services cover various functionalities that are kept in mobile phone technology for making payments, e-Wallets, peer-to-peer transfers (real-time money transfer between two people) and bank transfers. This platform is an initiative that has been implemented to boost the economy and, at the same time, to keep updated with technological advancements in this digital era.

In Europe, the implementation of Fintech in financial services is snowballing, which is parallel with high penetration rates of mobile phones in this digital era (Khraim, Shoubaki, \& Khraim, 2011). The number of Fintech usage through mobile phones has risen due to its direct connectivity with the internet. In Asia, numerous studies on the adoption of Fintech payment in developed countries such as Singapore, Korea, Brazil, China, and Taiwan have been carried out. For instance, the Investments in private Fintech firms based in the Asia-Pacific increased by $9.1 \%$ to $\$ 1.4$ billion during the second quarter of 2020, compared to the first quarter of year 2020 as reported by S\&P Global Market Intelligence (Faridi, 2020).

The presence of Fintech in Malaysia is still nascent but growing rapidly. The Director of Financial Development and Innovation, Bank Negara Malaysia (BNM) had stated that regulations have been issued by BNM and the Securities Commission of Malaysia (SCM) to support 
Fintech through the introduction of a Fintech regulatory sandbox (Fintech News Malaysia, 2020). The regulatory sandbox allows Fintech platforms to experiment with their solutions in a controlled environment, accompanied by appropriate safeguards for a limited period. The SCM has also released guidelines for P2P financing and equity crowdfunding. Fintech is associated with faster and cheaper transactions, but based on the PwC (2016), only $26 \%$ of Malaysians used those services, while another $74 \%$ of the citizens still doubted using technological equipment to conduct certain payment transactions especially using Fintech platforms. This percentage is measured by comparing e-payment usage in countries such as Singapore, Finland, South Korea, and England, where Malaysia stands last (PwC, 2016). This problem has arisen due to information security and privacy threats even though users are open-minded toward Fintech services.

The digital disruption brought by Fintech companies makes the traditional financial transaction less favorable as it is time consuming and involves complex procedures. As most of the time employed fresh graduates are at the workplace, they have insufficient time to conduct financial transactions over the counter. Therefore, these is a better alternative for them. Other than that, since Fintech disrupts traditional financial matters, it is then introduced as the future of financial technology. It is essential for fresh graduates to prepare themselves with complementary skills and competencies to handle these technologies, as they are the ones who will be working within these industries that are regarded as computer literate and IT savvy (Mathews, 2020). The Malaysian Ministry of Education (2019) had reported that the adoption of Fintech is still relatively low, compared to the yearly increment of fresh graduates in spite it is becoming the major financial alternative for consumers and businesses in Malaysia, (Jin, Seong, \& Kin, 2019). Acknowledging this fact, hence, an investigation on the acceptance of Fintech by employed fresh graduates is inevitable.

In a nutshell, from the discussion above it is crystal clear that the adoption rate of Fintech is still low and findings from developing countries such as Malaysia remain to be interesting, especially from the context of employed fresh graduates. Therefore, this research aimed to examine the factors that affect the acceptance of Fintech payment services. It was also an attempt to measure the relationships between performance expectancy, effort expectancy, social influence, facilitating condition and consumers' 
trust with the adoption of Fintech through the lens of the Unified Theory of Acceptance and Use of Technology (UTAUT). This research focussed solely on Fintech payment services, which is a subsegment of alternative payment methods.

The remainder of the paper is organized as follows. The next section presents the theoretical foundation and literature review. This is followed by hypothesis development and the research model. Subsequently, the description of the methodology is outlined. The result is presented in the following section. Finally, the discussion and conclusions are presented.

\section{LITERATURE REVIEW}

Fintech is derived from the combination of finance and technology, implying the implementation of innovative technologies such as smartphones and the Internet in improving the productivity and efficiency of financial services without the financial institution as an intermediary (Chuang, Liu, \& Koa, 2016). Fintech refers to companies that provide financial services, which primarily focus on the technology platform for innovative financial services products. It is not limited to specific areas (e.g., financing) or business models, but covers various high-tech systems in financial industries like mobile payments, loans, financing, money transfers, and even asset management (Arner, Barberis, \& Buckley, 2015). Arner et al. (2015) had posited the differences between traditional financial services and Fintech, where it is not a mere combination of information technology and financial services, but the implementation of technology into traditional services to expand their context. Fintech covers various transactions, including insurance technology, financial data, payment and banking systems and mobile banking, with payment services being the largest subcategory covered under Fintech (Szakiel, 2018). Fintech payment services have improved the way people do business. The tools provided by Fintech enable the consumers to track, manage and facilitate their finances remotely.

\section{Fintech in Malaysia}

The rise of Fintech in Malaysia, such as online banking and electronic payments, has contributed to an increase in the competitiveness of 
technology in Malaysia. Financial institutions offer services that continue to challenge and react to consumers' attitudes towards new technological products to gain market opportunities (Chong, William-Choo, Yip, Chan, Julian-Teh, \& Ng, 2019). Digital payments and mobile wallets are the most popular services currently on the rise in Malaysia, with many local Fintech companies working hard to expand their portfolio and create unique products for their local daily use (Rabin, 2020).

The Malaysian government has also taken some initiative to promote the use of Fintech. For instance, the government had announced an allocation of RM750 million to promote the adoption of Fintech payment services (Fong, 2020). Fong further showed that RM50 was credited to approximately 15 million Malaysians' e-wallet accounts in July 2020. Meanwhile, the Malaysia Digital Economy Corporation (MDEC) has also created a vibrant Fintech ecosystem and leveraged the expertise and knowledge in the field of Islamic Finance. This is important as Malaysia is ranked 32nd out of 121 (best performing countries) leading the group of upper-middle-income countries (Network Readiness Index, 2019). The framework evidenced that the Malaysian government had a great investment in the use of advanced technologies. These strategies are employed to promote Malaysia to become an advanced country that can keep up with other developed countries such as Singapore, United States and Japan. Hence, it is crucial for everyone in Malaysia to take the first step to adopt this technology as a contribution to boost the Malaysian economy.

\section{Factors Influencing the Adoption of Fintech}

The adoption of Fintech payment services will turn traditional transactions into a new and modern approach to enhance the efficiency of transactions (Kim, Choi, Park, \& Yeon, 2016). The benefits provided by Fintech, can drive of the adoption of the technology. Following are some of the factors influencing the adoption of Fintech.

\section{Performance expectancy}

Performance expectancy is described as the extent to which a consumer is expected to be improved using a program or technology to achieve job or performance gains (Venkatesh, Morris, Davis, \& Davis, 2003). The relationship between performance expectancy and the adoption of Fintech 
has been the subject of many research questions and the difference has always been in the context of Fintech application. All hypothesized that performance expectancy predicts the adoption of Fintech and most of them found evidence for this assumption (Abdullah, Rahman, \& Rahim, 2018; Keng-Soon, Choo-Yen San, Pui-Yee, Hong-Leong, \& The Shwu-Shing, 2019). People tend to use new technology when they believe that with the help of the application or the system, they can do their work more efficiently. Consumers are more likely to use and embrace new technology if they believe that the technologies are more helpful and useful in their everyday routines (Alalwan, Dwivedi, \& Rana, 2016). Individuals have been keen on the advantages that the system can provide, as opposed to other systems, and, more significantly, the advantages of the ease that the system can provide, which can be used everywhere and any time.

\section{Effort expectancy}

Effort expectancy is defined as "the degree of ease associated with the use of a system" (Venkatesh et al., 2003). Previous studies on the adoption of mobile applications supported the idea that the effort expectancy has an impact on the adoption of technology (Yu, 2012). It is supported by Davis (1989), where an individual adopts new technology not just by anticipating how good the system is, but also by how much the system is not difficult to use and requires free effort. The positive influence of effort expectancy on the adoption of technology has been frequently discussed in previous studies (Abrahão, Moriguchi, \& Andrade, 2016; Abdullah et al., 2018; Yahaya \& Ahmad, 2019). Individuals are looking into technology that is easy to manage and understand to ensure that all activities are performed in accordance with what has been expected. In this study, effort expectancy refers to users using Fintech payment services with ease and interacting with the technology without any doubt (Zhou, Lu, \& Wang, 2010).

\section{Social influences}

Social influences refer to the extent to which an individual perceives those important others believe he or she should apply the new system (Venkatesh et al., 2003). It is where others' opinions or suggestions regarding a given system or technology can influence another person to adopt the technology. The effect of adoption of new technology suggests that consumers are not only drawn by the advantages of Fintech but are also affected by the social circle of users who use it as well, such as family and 
friends (Chuang, Liu, \& Kao, 2016). The information and encouragement provided by the surrounding people play a dynamic role in contributing to the understanding of the consumer as well as influencing one's behavior in accepting the technology such as Fintech payment services. While some researchers have found social influence as the most salient predictor (Abrahão et al., 2016; Abdullah et al., 2018; Keng-Soon et al., 2019; Yahaya \& Ahmad, 2019), others have found that social influence had no significant influence (Chen, Chen, \& Chen, 2019; Alalwan et al., 2017). Social influence cannot be substantial if changes are just implemented. Thus, people with more confidence and experience are less influenced by social pressure. (Alalwan et al., 2017).

\section{Facilitating conditions}

Facilitating conditions are designated as the degree to which an individual believes that organizational and technical infrastructure exists to support the use of a system (Venkatesh et al., 2003). For instance, the use of Fintech like online banking platforms usually requires a special kind of skill, resources, and technical facilities to ensure smooth transactions (Alalwan et al., 2017). Similarly, for Fintech payment services, where facilitating conditions are needed to make it possible to use the services more efficiently. Several studies have shown that facilitating conditions have a positive and significant impact on the adoption of technology (Abdullah et al., 2018; Yahaya \& Ahmad, 2019; Zhou et al., 2019). Most researchers have found evidence for this relationship (Abdullah et al., 2018; Yahaya \& Ahmad, 2019), but Zhou, Owusu-Marfo, Asante Antwi, Antwi, Kachie, and Ampon-Wireko, (2019) concluded that facilitating conditions had no significant influence.

\section{Consumers' trust}

Consumers' trust is defined as a customer's belief in integrity, benevolence, and the capability of a system to enhance their readiness to depend on technology for financial transactions (Gefen \& Straub, 2003). Stewart and Jürjens (2018) believed that consumers' trust is crucial when involving virtual transactions and becomes a barrier in the adoption of new technology. Trust has been extensively studied and confirmed to be a critical factor foreseeing consumers' insights and the adoption of technology (Stewart \& Jürjens, 2018; AlHogail, 2018). Besides, consumers' trust is confirmed as the key factor in determining the likelihood of adoption of technology (Stewart \& Jürjens, 2018). Additionally, it is essential to maintain 
a secure feeling to ensure that the deal done between two parties is safe and reliable when performing a financial transaction as Stewart and Jürjens (2018) had urged that those dramatic changes in technology are associated with an increase in cyber-attacks. This phenomenon could bring huge economic damages to individuals, which then impair their trust towards these services (Kranz, Murmann, \& Michahelles, 2013).

\section{Theoretical Background}

\section{The Unified Theory of Acceptance and Use of Technology (UTAUT)}

Venkatesh et al. (2003) introduced the Unified Theory of Acceptance and Use of Technology (UTAUT) in 2003. Figure 1 below depicts the four constructs that will play a significant role as factors influencing the acceptance and usage of technology. He further added that UTAUT is alleged to account for 70 percent of technology adoption. UTAUT comprises performance expectancy, effort expectancy, social influence and facilitating conditions. From the theory, four key moderators are included, which are gender, age, experience, and voluntariness of use.

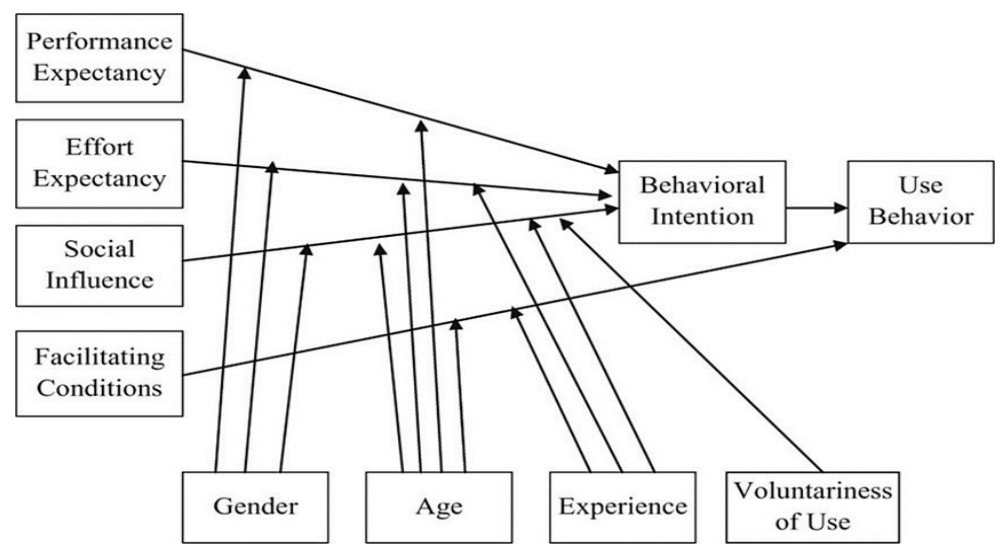

Figure 1: The Unified Theory of Acceptance and Use of Technology (Venkatesh et al., 2003)

In the context of this research, UTAUT as it deemed to serve as an excellent mechanism to measure the adoption of Fintech payment services among employed fresh graduates. Compared with other theories, UTAUT is more complex and will give a clearer view and a greater understanding 
of the adoption of Fintech payment services. However, UTAUT forgoes the security requirement, which is vital when considering adoption of technology (Shin, 2010). Consumers need to trust the services provided by a system to ensure that their transactions are safe and protected from any cyber threats. There are also four key moderators to the model: gender, age, experience, and voluntariness of use.

\section{Risky Technology Adoption Models (RTA)}

Security problems have been commonly debated in the acceptance of new technology, such as mobile payments, electronic commerce and mobile banking, yet risk-related concerns have received less attention. The impact of safety awareness is greater than technological risks, as it plays a key role in the adoption of technology (Gupta \& Xu, 2010). Likewise, security issues such as cyber-attack could bring substantial economic losses to consumers. Consumers' trust is vital in the adoption of technology to instill user confidence towards the services, as they would believe that their personal data is well protected (Stewart \& Jürjens, 2018). From this theory, consumers' trust was included as an independent variable to be tested further, which makes a total of five independent variables. Figure 2 shows the Risky Technology Adoption Models (RTA).

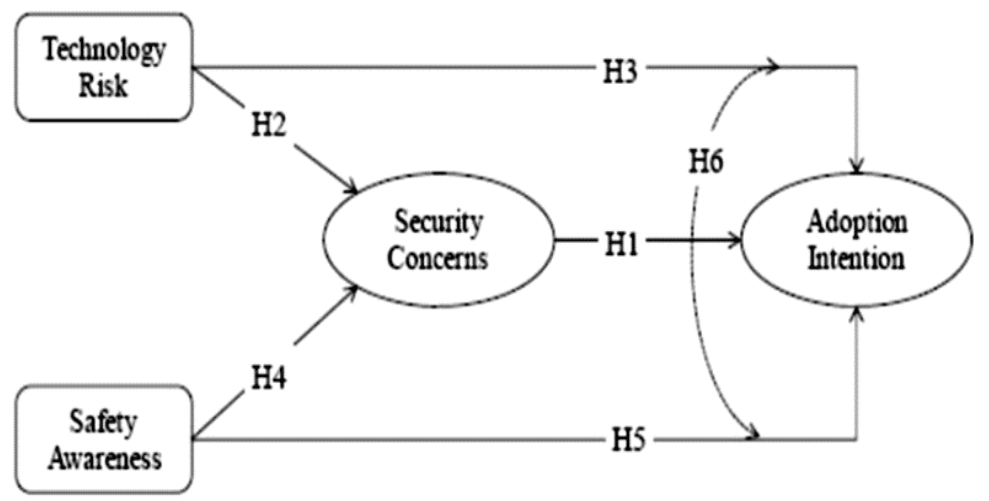

Figure 2: Risky Technology Adoption Models (Gupta \& Xu, 2010)

Due to the limitation of UTAUT that forgoes the need for security within the construct, the RTA model was employed to complement the absence of this dimension in deriving the research framework (see Figure 3 ). It is because consumers' trust is closely related to security concerns. 
Based on the RTA models, security concern is one of the elements used to predict the adoption of a specific technology. Therefore, this study focussed on five independent variables, which were performance expectancy, effort expectancy, social influence, facilitating conditions and consumers' trust as factors influencing the adoption of Fintech payment services among employed fresh graduates.

\section{Research Hypothesis}

\section{Performance expectancy}

The construct of performance expectancy is one of the key predictors towards the adoption of technology. Prior research has examined this relationship and results provided positive results in the context of mobile payments (Slade et al., 2015) and distribution of Zakat through Fintech (Yahaya \& Ahmad, 2019). However, there is no evidence of this relationship in the context of Fintech in the context of payment services solely. Since Fintech payment services enable consumers to perform fast payment transactions, such expectations can influence the adoption of technology. It is because people tend to use something or technology when benefits are derived from the usage. Hence, the following hypothesis was created:

H1: Performance expectancy significantly influences the adoption of Fintech payment services among employed fresh graduates.

\section{Effort expectancy}

Prior studies on the adoption of Fintech have supported the idea that effort expectancy affects the adoption of technology (Abdullah et al., 2018; Abrahão et al., 2016) but not in terms of Fintech payment services solely. Since Fintech payment services are easy to use, understandable and easy to communicate with, consumers' minimal effort to make payments will influence the adoption of technology. Other than that, effort expectancy is directly linked to the use of Fintech payment services among employed fresh graduates. This is because the use of Fintech payment services for daily transactions is most likely influenced by how simple or complicated it is to conduct the payment transaction and in the shortest time possible. Hence, if users realize that it is effortless to use the services provided by Fintech, they might not refrain from using it. Thus, the following hypothesis was proposed: 
H2: Effort expectancy significantly influences the adoption of Fintech payment services among employed fresh graduates.

\section{Social influence}

Prior researchers had integrated social influence into their research models in the context of the adoption of mobile technological services and have found that it brought a positive impact on the adoption of technology (Abdullah et al., 2018; Abrahão et al., 2016; Keng-Soon et al., 2019; Yahaya \& Ahmad, 2019). Dang et al. (2017) had argued that individuals believe that others want them to participate in certain activities; thus, social influence is seen as a significant factor affecting consumers' behavior. In a study on Fintech adoption in investment among Malaysians, Abdullah et al. (2018) found evidence to support the relationship between social influence and the adoption of technology in conducting investment activities. How people act or respond in their immediate environment is primarily based on the influence of the immediate social environment on what they do or not. The next hypothesis formulated was:

H3: Social influence significantly influences the adoption of Fintech payment services among employed fresh graduates.

\section{Facilitating conditions}

Abdullah et al. (2018) confirmed this relationship among the acceptance of users regarding Zakat distribution among "asnaf" through a Fintech platform. The study indicated that people are likely to have a high intention to adopt technology, but due to insufficient facilities such as mobile phones and technical knowledge resulting non-adoption of technology. Joshua and Koshy (2011) in their study of mobile banking had stated that easy access to computers and the Internet results in a higher adoption rate. As a result, higher facilitating conditions are expected to lead to higher adoption of technologies as well as Fintech payment services. Based on the findings, the following hypothesis was proposed:

H4: Facilitating conditions significantly influence the adoption of Fintech payment services among employed fresh graduates. 


\section{Consumers' trust}

Consumers' trust can be defined as the belief or confidence of the user in the degree to which a particular service can be regarded as having no security or privacy threats (Gao \& Yang, 2014). It is where consumers believe in mobile services with the expectation that the technology will be risk-free and will, in some ways, deliver intangible benefits at an unspecified time in the future. Consumers' trust is vital in adoption of technology, especially in monetary transactions. This is due to security structure reliability, where consumers need to trust that they would not have to encounter any hacker attacks and potential losses related to the adoption of new technology (Stewart \& Jürjens, 2018). Hence, higher consumers' trust is expected to lead to higher adoption of Fintech payment services. Based on the findings, the following hypothesis was proposed:

H5: Consumers' trust significantly influences the adoption of Fintech payment services among employed fresh graduates.

The following is the research framework used to test the hypotheses stated above,

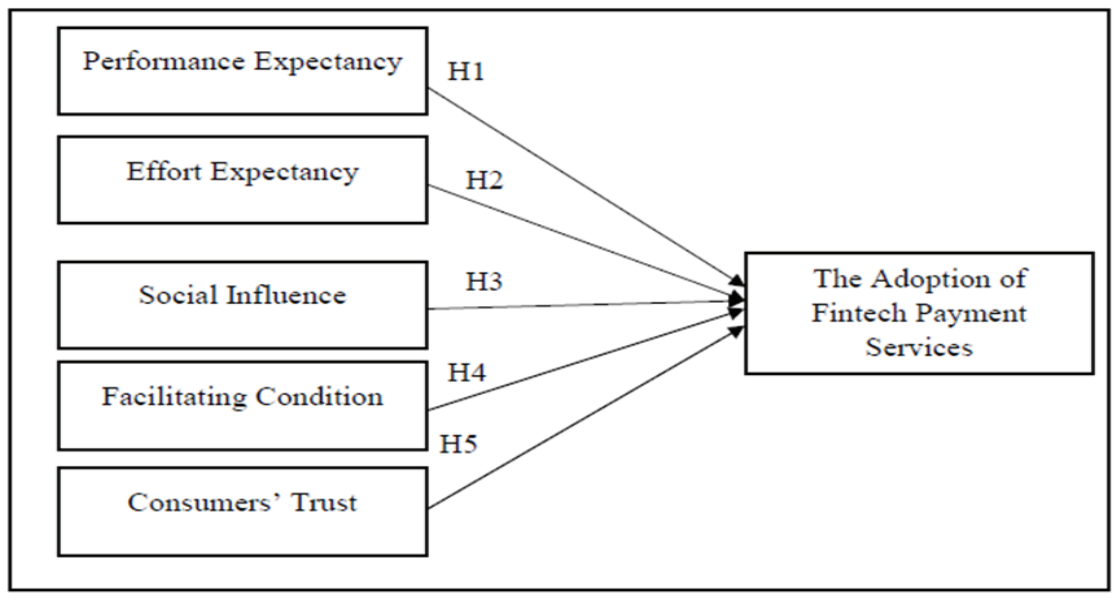

Figure 3 : Research Framework 


\section{METHODOLOGY}

\section{Data Collection Method and Sampling}

This study was conducted in Malaysia. The unit of analysis was employed fresh graduates in Malaysia. Employed fresh graduates were selected because it was the highest compared to the other employment status of fresh graduates. Thus, respondents were randomly selected from employed fresh graduates. Questionnaires were sent to 600 respondents. Out of the total 600 questionnaires distributed, 179 completed questionnaires were returned. Based on Sekaran and Bougie (2016), this study required at least 384 samples. One hundred seventy-nine (179) useful responses from the yielded a response rate of $30 \%(179 / 600 \times 100)$. As the acceptable response rate was $29.8 \%$, this rate was deemed acceptable and sufficient to represent the population (Sekaran \& Bougie, 2016).

\section{Survey Instruments}

This study used a questionnaire survey as the research instrument. The questionnaire consisted of three main sections; Section A, Section B and Section C, while Section B was divided into six subsections that represented the measurement for each independent variable, where each subsection consisted of 4 questions. Section A required general information on the demographic profile of the respondents, which included gender, age, level of education, type of institution (graduated from), year of graduation, job position, familiar Fintech payment services applications, usage frequencies and the reasons for choosing Fintech payment services. Lastly, in Section C, respondents were asked about their adoption of Fintech payment services in their daily transactions. This section represented the dependent variable. In determining the influencing factors on the adoption of Fintech payment services, a 5-point Likert Scale was used ranging from "strongly disagree" to "strongly agree". Most of the questions were adopted from Venkatesh et al. (2003) while some of the questions were adopted from the studies like Grabner- Krauter and Faullant (2018), Marakarkandy et al. (2017) and Patel and Patel (2018) (refer to Table 1). 


\section{Variable Measurement}

The questionnaire was designed to include all the variables in this study (i.e., Performance Expectancy, Effort Expectancy, Social Influence, Facilitating Condition, Consumers' Trust and The Adoption of Fintech Payment Services). Item measurement for the variables were adopted from various studies (see Table 1 for details).

Table 1: Measurement Items

\begin{tabular}{|c|c|c|}
\hline Construct & Items & References \\
\hline $\begin{array}{l}\text { Performance } \\
\text { Expectancy } \\
\text { (PE) }\end{array}$ & $\begin{array}{l}\text { PE1 - I believe the Fintech payment service is useful in } \\
\text { my daily transactions. PE2 - Fintech payment service } \\
\text { enables me to perform my payment transactions } \\
\text { faster. PE3 - Fintech payment service allows me to } \\
\text { do multitasking, such as while working, I can also pay } \\
\text { my bills. PE4 - Fintech payment services would bring } \\
\text { me greater convenience. }\end{array}$ & $\begin{array}{l}\text { Martins et al., } \\
\text { 2014; Venkatesh } \\
\text { et al., 2003; Zhou } \\
\text { et al., } 2010 .\end{array}$ \\
\hline $\begin{array}{l}\text { Effort } \\
\text { Expectancy } \\
\text { (EE) }\end{array}$ & $\begin{array}{l}\text { EE1 - The Fintech payment interface is clear and easy } \\
\text { to understand. EE2 - I can master the Fintech payment } \\
\text { service within a short period of time. EE3 - Fintech } \\
\text { payment service is easy to be used by anyone. EE4 - } \\
\text { The HELP and tutorial guide functions in the Fintech } \\
\text { payment system facilitates me to use the system better. }\end{array}$ & $\begin{array}{l}\text { Venkatesh et al., } \\
2003 \text {; Zhou et al., } \\
2010 .\end{array}$ \\
\hline $\begin{array}{l}\text { Social Influence } \\
\text { (SI) }\end{array}$ & $\begin{array}{l}\text { SI1 - People around me think I should use the Fintech } \\
\text { payment service. SI2 - My family members think I } \\
\text { should use the Fintech payment service. SI3 - social } \\
\text { media influences me to use the Fintech payment } \\
\text { service. SI4 - Advertisement in the mass media such } \\
\text { as in television, Internet, and radio influences me to } \\
\text { use Fintech payment service. }\end{array}$ & $\begin{array}{l}\text { Venkatesh et al., } \\
2003 \text {; Zhou et al., } \\
2010 .\end{array}$ \\
\hline
\end{tabular}

Facilitating FC1 - I use my mobile phone for the Fintech payment Venkatesh et al., Condition (FC) service. FC2 - I use other gadgets (laptop or tablet) for 2003.

Fintech payment service. FC3 - I do have the required knowledge to use the Fintech payment service. FC4 - Customer service is always available to assist me.

Consumers' CT1 - I feel secure using the Fintech payment services. Grabner-Krauter Trust (CT) CT2 - I believe Fintech payment services do protect my \& Faullant, 2008; personal information. CT3 - I believe Fintech payment Marakarkandy et services are safer than a cash basis. CT4 - I believe al., 2017, in the security of Fintech payment service.

The Adoption AF1 - I prefer to use the Fintech payment service Marakarkandy et of Fintech Payment Services $(\mathrm{AF})$ as compared to a cash basis while performing transactions. AF2 - I intend to use the Fintech payment service very soon. AF3 - As an existing user, I will Venkatesh et al., continue using the Fintech payment system. AF4 2003.

- I rely on Fintech payment service for my future transactions. 
The data in this study were analyzed using the Statistical Package for Social Sciences (SPSS) version 25 software. In this study, descriptive analysis was carried out on the influencing factors on the adoption of Fintech payment services. Hypotheses were analyzed using correlation and multiple regressions to examine the influence of performance expectancy, effort expectancy, social influence, facilitating condition, consumers' trust in the adoption of Fintech payment services among employed fresh graduates.

\section{RESULTS}

\section{Demographic Profile of Respondent}

The questionnaires were circulated through the social media platform to approximately 600 persons. The total number of responses received was 200 , but only 179 were usable as the remaining 21 responses received were incomplete and were from students who were not working. Based on Sekaran Bougie (2016), this population for the study was quite large and required at least 384 samples. But due to movement restriction this study only received 179 useful responses over the required sample, making it yield a response rate of $30 \%$. $(179 / 600 \times 100)$. As an acceptable response rate is $29.8 \%$ (Sekaran \& Bougie, 2016), this rate was deemed acceptable, and it was sufficient to represent the population. The respondent's demographic data were analyzed, which included gender, age, level of education, type of institution (graduated from), year of graduation, job position, familiar Fintech payment service application, frequency of usage and the reasons for choosing Fintech instead of cash.

Fresh graduates in this study were defined as someone who has started working after finishing his/her studies. Sometimes after finishing the bachelor's degree, graduates immediately pursue their education at the master's level and after that go to work. Hence, they are also fresh graduates. Same goes to the $\mathrm{PhD}$ level where there is a fast-track $\mathrm{PhD}$ program, where an excellent bachelor's degree graduate is given the opportunity to directly pursue his/her $\mathrm{PhD}$ without doing a master's degree and after that starts working. They also fresh graduates. Details of profiles are depicted in Table 2. 
Table 2: Demographic Profile of Respondents

\begin{tabular}{|c|c|c|c|}
\hline \multicolumn{2}{|c|}{ Demographic variable } & \multirow{2}{*}{$\begin{array}{c}\text { Frequency } \\
111\end{array}$} & \multirow{2}{*}{$\begin{array}{c}\text { Percentage } \\
62 \%\end{array}$} \\
\hline Gender & Male & & \\
\hline & Female & 68 & $38 \%$ \\
\hline \multirow[t]{4}{*}{ Age (years) } & 25 years old and below & 115 & $64.2 \%$ \\
\hline & 26 to 35 years old & 60 & $33.5 \%$ \\
\hline & 36 to 45 years old & 3 & $1.7 \%$ \\
\hline & 46 years old and above & 1 & $0.6 \%$ \\
\hline \multirow[t]{5}{*}{ Level of Education } & $\mathrm{PhD} /$ Master & 16 & $8.9 \%$ \\
\hline & Bachelor's degree & 141 & $78.8 \%$ \\
\hline & Diploma & 13 & $7.3 \%$ \\
\hline & Certificate & 7 & $3.9 \%$ \\
\hline & Other & 2 & $1.1 \%$ \\
\hline \multirow{3}{*}{$\begin{array}{l}\text { Type of Institution } \\
\text { (Graduated from) }\end{array}$} & Public University (IPTA) & 153 & $85.5 \%$ \\
\hline & Private University (IPTS) & 18 & $10.1 \%$ \\
\hline & TVET & 8 & $4.5 \%$ \\
\hline \multirow[t]{3}{*}{ Year of Graduating } & Below 1 year & 41 & $22.9 \%$ \\
\hline & From 1 to 2 years & 102 & $57.0 \%$ \\
\hline & From 2 to 3 years & 36 & $20.1 \%$ \\
\hline \multirow[t]{4}{*}{ Job Position's Level } & Management & 54 & $30.2 \%$ \\
\hline & Professional & 91 & $50.8 \%$ \\
\hline & Administrative & 30 & $16.8 \%$ \\
\hline & Other & 4 & $2.2 \%$ \\
\hline
\end{tabular}


Technology Acceptance of Financial Technology (Fintech)

\begin{tabular}{|c|c|c|c|c|}
\hline \multirow{18}{*}{$\begin{array}{l}\text { Fintech Payment Services } \\
\text { Application }\end{array}$} & \multirow{2}{*}{ PayPal } & 0p5.4 & 142 & $79.3 \%$ \\
\hline & & No & 37 & $20.7 \%$ \\
\hline & \multirow{2}{*}{ Ipay88 } & Yes & 117 & $65.4 \%$ \\
\hline & & No & 62 & $34.6 \%$ \\
\hline & \multirow{2}{*}{ Webcash } & Yes & 33 & $18.4 \%$ \\
\hline & & No & 146 & $81.6 \%$ \\
\hline & \multirow{2}{*}{ Boost } & Yes & 149 & $83.2 \%$ \\
\hline & & No & 30 & $16.8 \%$ \\
\hline & \multirow{2}{*}{ Touch ‘n Go E-Wallet } & Yes & 166 & $92.7 \%$ \\
\hline & & No & 13 & $7.3 \%$ \\
\hline & \multirow{2}{*}{ Fave } & Yes & 40 & $22.3 \%$ \\
\hline & & No & 139 & $77.7 \%$ \\
\hline & \multirow{2}{*}{ FPX } & Yes & 110 & $61.5 \%$ \\
\hline & & No & 69 & $38.5 \%$ \\
\hline & \multirow{2}{*}{ MOLPay } & Yes & 65 & $36.3 \%$ \\
\hline & & No & 114 & $63.7 \%$ \\
\hline & \multirow{2}{*}{ GrabPay } & Yes & 140 & $78.2 \%$ \\
\hline & & No & 39 & $21.8 \%$ \\
\hline \multirow{4}{*}{$\begin{array}{l}\text { Frequency of Usage of } \\
\text { Fintech Payment Services }\end{array}$} & A few times a month & \multicolumn{2}{|c|}{35} & $19.6 \%$ \\
\hline & A few times a week & \multicolumn{2}{|c|}{79} & $44.1 \%$ \\
\hline & Once a day & \multicolumn{2}{|c|}{52} & $29.1 \%$ \\
\hline & Several times a day & \multicolumn{2}{|c|}{13} & $7.3 \%$ \\
\hline \multirow{8}{*}{$\begin{array}{l}\text { Reasons to Choose } \\
\text { Fintech Payment Services }\end{array}$} & \multirow{2}{*}{ Cheap alternatives } & Yes & 140 & $78.2 \%$ \\
\hline & & No & 39 & $21.8 \%$ \\
\hline & \multirow[t]{2}{*}{ Fast transactions } & Yes & 166 & $92.7 \%$ \\
\hline & & No & 13 & $7.3 \%$ \\
\hline & \multirow{2}{*}{$\begin{array}{l}\text { No need to bring a lot of cash } \\
\text { at work }\end{array}$} & Yes & 115 & $64.2 \%$ \\
\hline & & No & 64 & $35.8 \%$ \\
\hline & \multirow[t]{2}{*}{ More secured } & Yes & 112 & $62.6 \%$ \\
\hline & & No & 67 & $37.4 \%$ \\
\hline
\end{tabular}

\section{Descriptive Analysis}

The overall mean score of performance expectancy was 4.40 , with a standard deviation of 0.487 , indicating that respondents believed the performance expectancy or benefits could be gained from using Fintech 
payment services (refer Table 3). Next, the overall mean score of effort expectancy was 4.44 with a standard deviation of 0.465 , indicating that respondents believed ease of use of the Fintech payment services could influence the adoption of Fintech payment services. Social influence scored a mean of 4.18 and a standard deviation of 0.566 showing that respondents believed people in their circle and the mass media had a high tendency to influence the adoption of Fintech payment services among employed fresh graduates. Moreover, the facilitating condition mean score was 4.37, with a standard deviation of 0.603 , indicating that respondents believed the facilitating conditions related to Fintech payment services could help them use the system better. Consumers' trusts mean score was 4.29 with a standard deviation of 0.595 implying that respondents only adopted Fintech payment services when they are highly confident regarding system security. The mean score for the adoption of Fintech payment services was 4.50 and the standard deviation was 0.445 showing that the reliance of respondents towards Fintech payment services was likely to increase the adoption of the system among employed fresh graduates.

Table 3: Result of Construct Assessment

\begin{tabular}{|c|c|c|c|c|c|c|}
\hline & Variables & Mean & $\begin{array}{l}\text { Standard } \\
\text { Deviation }\end{array}$ & $\begin{array}{l}\text { Cronbach } \\
\text { Alpha }\end{array}$ & Skewness & Kurtosis \\
\hline 1 & Performance Expectancy & 4.40 & 0.487 & 0.758 & -1.019 & 1.156 \\
\hline 2 & Effort Expectancy & 4.44 & 0.465 & 0.732 & -1.033 & 1.145 \\
\hline 3 & Social Influence & 4.18 & 0.566 & 0.703 & -0.687 & -.397 \\
\hline 4 & Facilitating Condition & 4.37 & 0.603 & 0.708 & -0.902 & -.050 \\
\hline 5 & Consumers' Trust & 4.29 & 0.595 & 0.840 & -1.363 & 2.532 \\
\hline 6 & $\begin{array}{l}\text { Adoption of Fintech } \\
\text { Payment Services }\end{array}$ & 4.50 & 0.445 & 0.702 & -1.275 & 1.844 \\
\hline
\end{tabular}

$\mathrm{N}=179$

All the 179 samples were assessed for normality of data based on the completed questionnaires. The skewness and kurtosis values for all the variables were between -3 and +3 . These results indicated that the mean scores of performance expectancy, effort expectancy, social influence, facilitating condition, consumers' trust and the adoption of Fintech payment services were normally distributed. This is because the range of skewness and kurtosis of the normal data lied between -3.00 and +3.00 (Mustapha \& Siaw, 2012). 


\section{Validity Test}

A validity test was performed to verify the instruments and data used for the analysis. Since the critical value of the loading factor for the rotation matrix was set to 0.4 , any element that scored less than 0.4 were not considered important. Based on this, all the items were above the acceptance value of 0.4 and as shown in Table 4 below:

Table 4: Measurement of Model Output

\begin{tabular}{|c|c|c|}
\hline Variables & Items & Factor Loading \\
\hline \multirow[t]{4}{*}{ Performance Expectancy } & PE1 & .554 \\
\hline & PE2 & .673 \\
\hline & PE3 & .601 \\
\hline & PE4 & .620 \\
\hline \multirow[t]{4}{*}{ Effort Expectancy } & EE1 & .539 \\
\hline & EE2 & .660 \\
\hline & EE3 & .722 \\
\hline & EE4 & .495 \\
\hline \multirow[t]{4}{*}{ Social Influences } & $\mathrm{SI} 1$ & .672 \\
\hline & $\mathrm{SI} 2$ & .504 \\
\hline & $\mathrm{SI} 3$ & .546 \\
\hline & $\mathrm{S} 14$ & .570 \\
\hline \multirow{4}{*}{ Facilitating Conditions } & FC1 & .501 \\
\hline & FC2 & .682 \\
\hline & FC3 & .571 \\
\hline & FC4 & .617 \\
\hline \multirow[t]{4}{*}{ Consumers' Trust } & CT1 & .695 \\
\hline & CT2 & .655 \\
\hline & CT3 & .582 \\
\hline & CT4 & .726 \\
\hline \multirow[t]{4}{*}{ Adoption of Fintech Payment Services } & AF1 & .536 \\
\hline & AF2 & .454 \\
\hline & AF3 & .415 \\
\hline & AF4 & .550 \\
\hline
\end{tabular}

\section{Reliability Test}

Cronbach's alpha value for performance expectancy (PE), effort expectancy (EE), social influence (SI), facilitating condition (FC), consumers' trust (CT) and the adoption of Fintech payment services (AF) 
were $0.758,0.732,0.703,0.708$ and 0.840 , respectively. The results indicated that the reliability for items PE, EE, SI, FC was acceptable, and CT was good. Meanwhile, for the dependent variable, which is the adoption of Fintech payment services (AF), the alpha value was 0.702 . It also indicated that all the items used in the dependent variable were reliable (George \& Mallery, 2003).

\section{Correlation Analysis}

Table 5 indicates the correlation between all the main variables in this study. Two variables with bivariate correlation of 0.9 or more in the same analysis should not be included (Pallant, 2011). Based on the results, there was a significant positive little association between performance expectancy and the adoption of Fintech payment services as $r=0.297$, $(p<0.001)$. Hence, an increase in performance expectancy was associated with little increase in the adoption of Fintech payment services and vice versa.

Table 5: Correlation Matrix

\begin{tabular}{|c|c|c|c|c|c|c|}
\hline Variables & AF & PE & EE & SI & FC & CT \\
\hline $\mathrm{AF}$ & 1 & & & & & \\
\hline $\mathrm{PE}$ & $.297^{\star \star}$ & 1 & & & & \\
\hline EE & $.531^{* *}$ & $.340^{\star \star}$ & 1 & & & \\
\hline $\mathrm{SI}$ & $.256^{\star \star}$ & $.169^{*}$ & $.269^{\star \star}$ & 1 & & \\
\hline FC & $.149^{*}$ & .138 & $.149^{*}$ & $.305^{\star *}$ & 1 & \\
\hline CT & $.636^{\star \star}$ & $.292^{* \star}$ & $.480^{* *}$ & $.351^{* *}$ & $.251^{* *}$ & 1 \\
\hline
\end{tabular}

**. Correlation is significant at the $\mathbf{0 . 0 1}$ level (2-tailed).

*. Correlation is significant at the $\mathbf{0 . 0 5}$ level (2-tailed).

AF: (Adoption of Fintech Payment Services); PE: (Performance Expectancy); EE: (Effort Expectancy); SI: (Social Influence); FC: (Facilitating Condition); CT: (Consumers' Trust)

Next, there was a significant positive moderate correlation between effort expectancy and the adoption of Fintech payment services as $r=0.531$, $(p<0.001)$. Hence, an increase in effort expectancy was associated with a moderate increase in the adoption of Fintech payment services and vice versa. For the next variable, there was a significant positive little association between social influence and the adoption of Fintech payment services as $\mathrm{r}=0.256$, $\mathrm{p}$-value less than $0.05(\mathrm{p}=0.001)$. Hence, an increase in social influence was associated with a little increase in the adoption of Fintech payment services and vice versa. 
However, for the fourth independent variable, which was facilitating condition, had a significant positive association but not correlated with the adoption of Fintech payment services as $r=0.149$, the $p$-value is 0.049 (p $<0.05)$. When there were changes in facilitating conditions, it will have no impact on the adoption of Fintech payment services. For the last independent variable, there was a significant positive moderate association between consumers' trust and the adoption of Fintech payment services as $r=0.636$, $(\mathrm{p}<0.001)$. Hence, an increase in consumers' trust was associated with a moderate increase in the adoption of Fintech payment services and vice versa. The independent variables used in this study did not involve any multicollinearity problem as the correlation value was less than 0.90 . This result indicated that all variables can be retained as no multicollinearity issue existed. Therefore, further analyses for testing the research hypotheses were conducted using multiple regression analysis.

\section{Regression Analysis}

Multiple regression analysis of the relationship between five constructs (performance expectancy, effort expectancy, social influence, facilitating condition and consumers' trust) with the adoption of Fintech payment services among employed fresh graduates (Model 1) are shown in Table 6.

Table 6: Model's Results and Values

\begin{tabular}{cccc}
\hline Model & R Square & F-Value & P-Value \\
\hline 1 & 0.474 & 31.151 & 0.000 \\
\hline
\end{tabular}

To evaluate the hypotheses for this study, multiple regression analysis was used to determine whether there was a significant relationship between the independent variables (performance expectancy, effort expectancy, social influence, facilitating conditions and consumers' trust) and the adoption of Fintech payment services among employed fresh graduates.

As documented in Table 6 , the $\mathrm{R}$ square $\left(\mathrm{r}^{2}\right)$ value was 0.474 showing that all the five independent variables selected for this study were able to explain $47.4 \%$ of the variation in the dependent variable (the adoption of Fintech payment services among employed fresh graduates). Meanwhile, the remaining $52.6 \%$ of the changes were affected by other factors that were not in this study. The independent variables were sufficient to be classified 
as an explanatory variable given that the p-value was less than 0.1 , hence the result proved that the research model was significant and fit for this study. Therefore, the multiple linear regression equation for Model 1 was as follows:

$$
y=\alpha+\beta_{1} x_{1}+\beta_{2} x_{2}+\beta_{3} x_{3}+\beta_{4} x_{4}+\beta_{5} x_{5}
$$

Where,

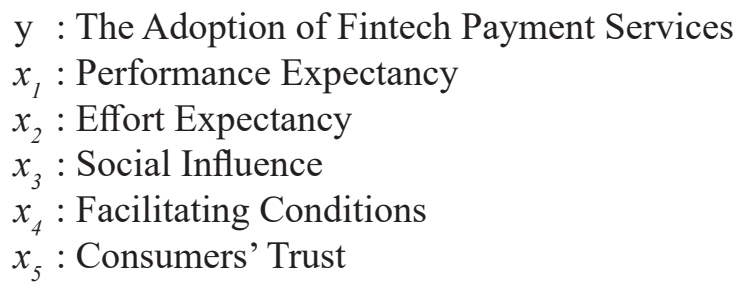

From the model above, the $\beta$ value for the independent variables indicated the impact of the independent variables toward the dependent variable. From this study, performance expectancy was $(\beta=0.057, \mathrm{p}<$ $0.001)$, effort expectancy was $(\beta=0.265, \mathrm{p}<0.001)$, social influence was $(\beta=0.006, p=0.903)$, facilitating conditions was $(\beta=-0.019, \mathrm{p}=$ $0.656)$ and consumers' trust was $(\beta=0.365, \mathrm{p}<0.001)$. On an average, an increase of one percent of performance expectancy, effort expectancy, social influence and consumers' trust, the adoption of Fintech payment services among employed fresh graduates will increase by $5.7 \%, 26.5 \%, 0.6 \%$ and $36.5 \%$, respectively. However, an increase of one percent of facilitating conditions will likely decrease the adoption of Fintech payment services among employed fresh graduates by $1.9 \%$

Table 7: The Coefficients Values of the Model 1

\begin{tabular}{lccccc}
\hline & B & Std. Error & Beta & t-statistic & Sig \\
\hline (Constant) & 1.566 & .319 & & 4.916 & .000 \\
\hline Performance Expectancy & .057 & .054 & .063 & 4.052 & .000 \\
\hline Effort Expectancy & .265 & .062 & .277 & 4.248 & .000 \\
\hline Social Influence & .006 & .048 & .007 & .122 & .903 \\
\hline Facilitating Condition & -.019 & .043 & -.026 & -.447 & .656 \\
\hline Consumers' Trust & .365 & .050 & .488 & 7.352 & .000 \\
\hline
\end{tabular}


As shown in Table 7, all the independent variables, except facilitating conditions, had a positive correlation with the adoption of Fintech payment services. However, among these variables, only three of them had a significant value of below 0.05 , which are performance expectancy, effort expectancy and consumers' trust, while the others had a significance value of greater than 0.05 . These reflected that out of five variables proposed as determinant factors, only three variables: performance expectancy, effort expectancy and consumers' trust, positively and significantly influenced the adoption of Fintech payment services among employed fresh graduates. Consumers' trust posited the strongest influence $(\beta=0.365)$, followed by $(\beta=0.265)$ effort expectancy and performance expectancy $(\beta=0.057)$.

\section{Hypotheses Testing}

Out of the five hypotheses proposed, three hypotheses were significant for this study. Hypotheses for this study were analyzed using multiple regression analysis and a summary result is presented in Table 8 below:

Table 8: Summary of Results

\begin{tabular}{llll}
\hline No & \multicolumn{1}{c}{ IV } & \multicolumn{1}{c}{ Hypotheses } & \multicolumn{1}{c}{ Findings } \\
\hline H1 & $\begin{array}{l}\text { Performance } \\
\text { Expectancy } \\
\text { (PE) }\end{array}$ & $\begin{array}{l}\text { Performance expectancy significantly } \\
\text { influences the adoption of Fintech } \\
\text { payment services among employed } \\
\text { fresh graduates. }\end{array}$ & $\begin{array}{l}\text { There is a significant positive } \\
\text { relationship between PE and } \\
\text { the adoption of Fintech payment } \\
\text { services among employed fresh } \\
\text { graduates. }\end{array}$ \\
\hline H2 & $\begin{array}{l}\text { Effort } \\
\text { Expectancy } \\
\text { (EE) }\end{array}$ & $\begin{array}{l}\text { Effort expectancy significantly } \\
\text { influences the adoption of Fintech } \\
\text { payment services among employed } \\
\text { fresh graduates. }\end{array}$ & $\begin{array}{l}\text { There is a significant positive } \\
\text { relationship between EE and } \\
\text { the adoption of Fintech payment } \\
\text { services among employed fresh } \\
\text { graduates. }\end{array}$ \\
\hline H3 & $\begin{array}{l}\text { Social } \\
\text { Influence (SI) }\end{array}$ & $\begin{array}{l}\text { Social influence significantly influences } \\
\text { the adoption of Fintech payment } \\
\text { services among employed fresh } \\
\text { graduates. }\end{array}$ & $\begin{array}{l}\text { There is no significant positive } \\
\text { relationship between SI and the } \\
\text { adoption of Fintech payment } \\
\text { services among employed fresh } \\
\text { graduates. }\end{array}$ \\
\hline H4 & $\begin{array}{l}\text { Facilitating } \\
\text { Condition } \\
\text { (FC) }\end{array}$ & $\begin{array}{l}\text { Facilitating conditions significantly } \\
\text { influence the adoption of Fintech } \\
\text { payment services among employed } \\
\text { fresh graduates. }\end{array}$ & $\begin{array}{l}\text { There is no significant negative } \\
\text { relationship between FC and the } \\
\text { adoption of Fintech payment } \\
\text { services among employed fresh } \\
\text { graduates. }\end{array}$ \\
\hline H5 & $\begin{array}{l}\text { Consumers' } \\
\text { Trust (CT) }\end{array}$ & $\begin{array}{l}\text { Consumers' trust significantly } \\
\text { influences the adoption of Fintech } \\
\text { payment services among employed } \\
\text { fresh graduates. }\end{array}$ & $\begin{array}{l}\text { There is a significant positive } \\
\text { relationship between CT and } \\
\text { the adoption of Fintech payment } \\
\text { services among employed fresh } \\
\text { graduates. }\end{array}$ \\
\hline & & &
\end{tabular}




\section{DISCUSSION}

The first objective of this study was to examine the influence of performance expectancy towards the adoption of Fintech payment services among employed fresh graduates. The results indicated that performance expectancy exerted a significant influence on the adoption of Fintech payment services among employed fresh graduates. These findings are supported by Abrahão et al. (2016), Ramos (2017) and Yahaya and Ahmad (2019), which suggested that the adoption of Fintech payment services is influenced by the benefits that can be obtained from using the system.

The second objective of this study was to examine the influence of effort expectancy towards the adoption of Fintech payment services among employed fresh graduates. The results of the test showed that effort expectancy was found to have a significant effect on the adoption of Fintech payment services among employed fresh graduates. These findings are in line with a few past studies, including Abdullah et al. (2018), Abrahão et al. (2016), which suggested less effort to use the system will likely influence the adoption of the technology. It is because people tend to avoid using a complicated system to overcome human errors especially while performing monetary transactions.

The third objective of this study was to examine the influence of social influence on the adoption of Fintech payment services among employed fresh graduates. This finding is contrary to the result of past studies such as Abdullah et al. (2018), Abrahão et al. (2016), Keng-Soon et al. (2019) and Yahaya and Ahmad (2019). These past studies concluded that social influence had a significant relationship with the adoption of Fintech. In contrast, the current study implied that the adoption of Fintech payment services is not influenced by the surrounding, but it comes from a voluntary action to adopt a technology. This finding is like several studies such Alalwan et al. (2017) and Chen et al. (2019), where individuals seemed to be less interested in the recommendations and attitudes of their reference groups (i.e., family, friends, colleagues) regarding the adoption of technology. It is because the adoption of technology is a voluntary action and is often conducted solo. 
The fourth objective of this study was to examine the influence of facilitating conditions towards the adoption of Fintech payment services among employed fresh graduates. The results indicated that facilitating conditions were insignificant in influencing the adoption of Fintech payment services among employed fresh graduates. This finding contrasts with past studies such as Abdullah et al. (2018) and Yahaya and Ahmad (2019). These past studies concluded that facilitating conditions have a significant relationship with the adoption of Fintech. This study it had the same results as Zhou et al. (2019), where other factors related to Fintech payment services such as customer service and technical knowledge, did not influence the adoption of Fintech if they had their own smartphone no matter how bad the facilities which are provided by the system administrator.

The fifth objective of this study was to examine the influence of consumers' trust towards the adoption of Fintech payment services among employed fresh graduates. The result indicated that consumers' trust had a significant influence on the adoption of Fintech payment services among employed fresh graduates. This result is consistent with a few past studies such as Alhogail (2018) and Stewart and Jürjens (2018). They concluded that consumers' trust does influence the adoption of Fintech. Yet, consumers' trust alone does not guarantee high adoption among users. Good security will increase consumers' trust, thus increasing the adoption of Fintech payment services.

\section{CONCLUSION}

Based on the results, out of five hypotheses developed, three hypotheses, $\mathrm{H} 1, \mathrm{H} 2$ and $\mathrm{H} 5$, were supported, while the other two $\mathrm{H} 3$ and $\mathrm{H} 4$, were rejected. This indicated that performance expectancy, effort expectancy and consumers' trust influence the adoption of Fintech payment services among employed fresh graduates. The finding in this study showed that social influence was not significant in influencing the adoption of Fintech payment services because it is not influenced by the surrounding, but it comes from a voluntary action to adopt the technology. Meanwhile, facilitating conditions was also not significant because other facilities related to Fintech payment services such as customer service and technical knowledge did not influence the adoption of Fintech if they had their own smartphone no matter how bad the facilities provided by the system administrator are. 
From the theoretical perspective, this study sheds new light on a new topic, which has not been studied before. Most past researchers explored Fintech as a whole and there were very few studies on specific Fintech services. Therefore, this study attempted to fill the gap in the literature and contribute to the existing literature about Fintech companies. Besides, some findings contradict with those in the current literature. Indeed, the rapid increase of Fintech services has the potential to increase Malaysia's economic growth by increasing its efficiency because the emergence of technology can effectively turn savings into an investment due to the reduction of human capital and infrastructure.

From a practical perspective, the findings of this study could offer financial institutions or other related parties a better understanding of defining the internal or external factors that influence the adoption of Fintech services among current and potential users. This understanding will eventually help system administrators to explore what is insufficient and they will be able to identify other factors that could be implemented in their current system.

The limitation of this study pertains to sample description. This is because the largest segment of respondents in the study were young, welleducated, and had adequate experience with computers and the Internet. This raises concerns about the applicability of the outcomes to other groups of the current population that have different characteristics such as age, income, education level, gender, and experience with technology. Other than that, this study is limited to a quantitative research method because of time and cost constraints. Despite that, this quantitative study was successfully completed, but if a qualitative research or a mixed-mode research was adopted, the expected outcome will be much wider compared to only a quantitative approach.

The future research direction includes adding the key moderators of the UTAUT (e.g., gender, age, experience, and the voluntariness of use) into the study to identify whether it will or not affect the adoption of Fintech payment services or any other service related to Fintech. By adding this, it could generate different perspectives and research results. Besides that, Fintech covers a broad area which includes crowdfunding, lending, blockchain and many more. For future research, it is suggested that researchers study another 
context of Fintech such as blockchain to yield a more comprehensive and better view in understanding of Fintech.

\section{ACKNOWLEDGEMENT}

We would like to thank the anonymous reviewers for their useful suggestions in accomplishing this paper. Our utmost gratitude also goes to Faculty of Accountancy, UiTM Selangor, Kampus Puncak Alam and IRMI of University Teknologi MARA (UiTM) in providing the financial support under DDF grant (Geran Dana Dalaman) (600-TNCPI/5/3/DDF (002/2021).

\section{REFERENCES}

Abdullah, E. M. E., Rahman, A. A., \& Rahim, R. A. (2018). Adoption of financial technology (Fintech) in mutual fund/ unit trust investment among Malaysians: Unified Theory of Acceptance and Use of Technology (UTAUT). International Journal of Engineering and Technology (UAE), 7(2), 110-118.

Abrahão, R. de S., Moriguchi, S. N., \& Andrade, D. F. (2016). Intention of adoption of mobile payment: An analysis in the light of the Unified Theory of Acceptance and Use of Technology (UTAUT). RAI Revista de Administração e Inovação, 13(3), 221-230.

Alalwan, A. A., Dwivedi, Y. K., \& Rana, N. P. (2017). Factors influencing adoption of mobile banking by Jordanian bank customers: Extending UTAUT2 with trust. International Journal of Information Management, 37(3), 99-110.

Alhogail, A. (2018). Improving IoT technology adoption through improving consumer trust. Technologies, 6(3), 64.

Arner, D. W., Barberis, J., \& Buckley, R. P. (2015). The evolution of Fintech: A new post-crisis paradigm. Georgetown Journal of International Law, 47, 1271-1319. 
Chen, W. C., Chen, C. W., \& Chen, W. K. (2019). Drivers of mobile payment acceptance in China: An empirical investigation. Information (Switzerland), 10(12), 1-20.

Chong, T.-P., William Choo, K.-S., Yip, Y.-S., Chan, P.-Y., Julian Teh, H.L., \& Ng, S.-S. (2019). An adoption of Fintech service in Malaysia. Southeast Asia Journal of Contemporary Business, Economics and Law, 18(5), 73-92.

Chuang, L. M., Liu, C. C., \& Kao, H. K. (2016). The adoption of fintech service: TAM perspective. International Journal of Management and Administrative Sciences, 3(7), 1-15.

Dang, Y. M., Zhang, Y. G., \& Morgan, J. (2017). Integrating switching costs to information systems adoption: An empirical study on learning management systems. Information Systems Frontiers, 19(3), 625-644.

Davis, F. D. (1989). Perceived usefulness, perceived ease of use, and user acceptance of information technology. MIS Quarterly, 13(3), 319-340.

Dorfleitner, G., Hornuf, L., Schmitt, M., \& Weber, M. (2017). International position of the German FinTech market. In FinTech in Germany (pp. 47-54). Springer, Cham.

Ernst \& Young. (2016). German FinTech landscape: Opportunity for RheinMain-Neckar.

Faridi, O. (2020). Retrieved from https://www.crowdfundinsider.co $\mathrm{m} / 2020 / 08 / 165717$-Fintech-investments-in-asia-pacific-surged-9-1to-1-4-billion-during-q2-2020-as-investors-shift-focus-from-india-toaustralia-other-regions-report/

Fintech News Malaysia. (2020, August 20). Fintech News Malaysia. Retrieved from https://Fintechnews.my/24573/various/bnm-directorsuhaimi-ali-explains-Fintech-regulation-in-malaysia.

Fong, V. (2020). Malaysia to spend RM 1.2 billion promoting e-wallets in 2020. Fintech News Malaysia. Retrieved from https://fintechnews.m y/23971/e-wallets-malaysia/e-wallet-malaysia-pejana 
Gao, S., \& Yang, Y. (2014). The role of trust towards the adoption of mobile services in China: An empirical study. IFIP Advances in Information and Communication Technology, 445, 46-57.

Gefen, D., \& Straub, D. (2003). Managing user trust in B2C e-services. e-Service, 2(2), 7-24.

George, D., \& Mallery, P. (2003). Using SPSS for Windows step by step: A simple guide and reference ( ${ }^{\text {th }}$ ed.). London: Pearson Education.

Grabner-Krauter, S., \& Faullant, R. (2008). Consumer acceptance of internet banking: The influence of internet trust. International Journal of Bank Marketing, 26(7), 483-504.

Gupta, S., \& Xu, H. (2010). Examining the relative influence of risk and control on intention to adopt risky technologies. Journal of Technology Management \& Innovation, 5(4), 22-37.

Jin, C. C., Seong, L. C., \& Khin, A. A. (2019). Factors affecting the consumer acceptance towards Fintech products and services in Malaysia. International Journal of Asian Social Science, 9(1), 59-65.

Joshua, A. J., \& Koshy, M. P. (2011). Usage patterns of electronic banking services by urban educated customers: Glimpses from India. Journal of Internet Banking and Commerce, 16(1), 1-12.

Keng-Soon, C., Choo Yen-San, W., Pui-Yee, Y., Hong-Leong, C., \& Teh Shwu-Shing, J. (2019). An adoption of Fintech service in Malaysia. Southeast Asia Journal of Contemporary Business, Economics and Law, 18(5), 73-92.

Khraim, H. S., Al Shoubaki, Y. E., \& Khraim, A. S. (2011). Factors affecting Jordanian consumers' adoption of mobile banking services. International Journal of Business and Social Science, 2(20), 96-105.

Kim, Y., Choi, J., Park, Y. J., \& Yeon, J. (2016). The adoption of mobile payment services for "Fintech". International Journal of Applied Engineering Research, 11(2), 1058-1061. 
Kranz, M., Murmann, L., \& Michahelles, F. (2013). Research in the large: Challenges for large-scale mobile application research - A case study about NFC adoption using gamification via an app store. International Journal of Mobile Human Computer Interaction (IJMHCI), 5(1), 45-61.

Marakarkandy, B., Yajnik, N., \& Dasgupta, C. (2017). Enabling internet banking adoption: An empirical examination with an augmented technology acceptance model (TAM). Journal of Enterprise Information Management, 30(2), 263-294.

Martins, C., Oliveira, T., \& Popovič, A. (2014). Understanding the Internet banking adoption: A unified theory of acceptance and use of technology and perceived risk application. International Journal of Information Management, 34(1), 1-13.

Mathews, M. S. (2020). Trust fresh graduates to deliver. New Straits Times. Retrieved from https:/www.nst.com.my/opinion/letters/2020/02/568 669/trust-fresh-graduates-deliver

Ministry of Education. (2019). Statistik Pendidikan Tinggi 2018. Statistik Pendidikan Tinggi, 161-171.

Mustapha, M., \& Siaw, L. (2012). Whistle blowing: Perceptions of future accountants. International Proceedings of Economics Development and Research, 38, 135-139.

Network Readiness Index. (2019). Retrieved from https:// networkreadinessindex.org/wp-content/uploads/2020/03/The-NetworkReadiness-Index-2019-New-version-March-2020.pdf.

Pallant, J. (2011). A step-by-step guide to data analysis using SPSS. Allen and Unwin.

Patel, K. J., \& Patel, H. J. (2018). Adoption of internet banking services in Gujarat: An extension of TAM with perceived security and social influence. International Journal of Bank Marketing, 36(1), 147-169. 
PwC. (2016). Catching the Fintech wave. Price Waterhouse Coopers Journal. Retrieved from https://www.pwc.com/my/en/assets/publicat ions/2016-pwc-aicb-catching-the-Fintech-wave.pdf.

Rabin, K. (2020). Malaysia is the latest country to hop on the fintech trend. Finextra. Retrieved from https://www.finextra.com/blogposting/ 18505/ malaysia-is-the-latest-country-to-hop-on-the-fintech-trend

Ramos, F. A. B. (2017). Accessing the determinants of behavioral intention to adopt fintech services among the millennial generation (Doctoral dissertation).

Sekaran, U., \& Bougie, R. J. (2016). Research methods for business: A skill building approach ( $7^{\text {th }}$ ed.). Wiley PLUS Learning Space Card. Wiley.

Shin, D. H. (2010). Ubiquitous computing acceptance model: End user concern about security, privacy, and risk. International Journal of Mobile Communications, 8(2), 169-186.

Slade, E. L., Dwivedi, Y. K., Piercy, N. C., \& Williams, M. D. (2015). Modeling consumers' adoption intentions of remote mobile payments in the United Kingdom: Extending UTAUT with innovativeness, risk, and trust. Psychology and Marketing, 32(8), 860-873.

Stewart, H., \& Jürjens, J. (2018). Data security and consumer trust in Fintech innovation in Germany. Information and Computer Security, 26(1), 109-128.

Szakiel, P. (2018). What is fintech: A beginner's guide to financial technology in 2019. Retrieved at: https://learn.g2.com/Fintech

Venkatesh, V., Morris, M. G., Davis, G. B., \& Davis, F. D. (2003). User acceptance of information technology: Toward a unified view. MIS Quarterly, 425-478.

Yahaya, M. H., \& Ahmad, K. (2019). Factors affecting the acceptance of financial technology among asnaf for the distribution of zakat in Selangor - A study using UTAUT. Journal of Islamic Finance, 8, 35-46. 
Yu, C. S. (2012). Factors affecting individuals to adopt mobile banking: Empirical evidence from the UTAUT model. Journal of Electronic Commerce Research, 13(2), 104-121.

Zhou, L. L., Owusu-Marfo, J., Asante Antwi, H., Antwi, M. O., Kachie, A. D. T., \& Ampon-Wireko, S. (2019). Assessment of the social influence and facilitating conditions that support nurses' adoption of hospital electronic information management systems (HEIMS) in Ghana using the Unified Theory of Acceptance and Use of Technology (UTAUT) model. BMC Medical Informatics and Decision Making, 19(1), 230.

Zhou, T., Lu, Y., \& Wang, B. (2010). Integrating TTF and UTAUT to explain mobile banking user adoption. Computers in Human Behavior, 26(4), 760-767. 